\title{
Glaciecola chathamensis sp. nov., a novel marine polysaccharide-producing bacterium
}

\author{
Hidetoshi Matsuyama, ${ }^{1}$ Toshikazu Hirabayashi, ${ }^{1}$ Hirokazu Kasahara, ${ }^{1}$ \\ Hideki Minami, ${ }^{2}$ Tamotsu Hoshino ${ }^{3}$ and Isao Yumoto $^{3}$ \\ 1,2Department of Bioscience and Technology ${ }^{1}$ and Department of Marine Science and \\ Technology2, School of Engineering, Hokkaido Tokai University, Minamisawa, Minami-ku, \\ Sapporo 005-8601, Japan \\ ${ }^{3}$ Research Institute of Genome-based Biofactory, National Institute of Advanced Industrial \\ Science and Technology (AIST), Tsukisamu-Higashi, Toyohira-ku, Sapporo 062-8517, Japan
}

\begin{abstract}
Two novel exopolysaccharide-producing bacteria, strains $\mathrm{S} 18 \mathrm{~K} 6^{\top}$ and $\mathrm{S} 18 \mathrm{~K} 5$, were isolated from Pacific Ocean sediment. The isolates were Gram-negative, motile, strictly aerobic chemoheterotrophic bacteria. The DNA G $+C$ contents of strains $S 18 \mathrm{~K}^{\top}$ and $\mathrm{S} 18 \mathrm{~K} 5$ were $44 \cdot 8$ and $46.3 \mathrm{~mol} \%$, respectively. DNA-DNA relatedness between the two strains was $70 \%$. Major fatty acids were hexadecanoic acid $\left(\mathrm{C}_{16: 0}\right)$, hexadecenoic acid $\left(\mathrm{C}_{16: 1} \omega 7 \mathrm{c}\right)$ and octadecenoic acid $\left(\mathrm{C}_{18: 1} \omega 7 \mathrm{c}\right)$. 16S rRNA gene sequence, chemotaxonomic and morphological data indicated that these strains clearly belonged to the genus Glaciecola. Based on phenotypic properties and DNA-DNA hybridization data, strains $\mathrm{S} 18 \mathrm{~K} 6^{\top}$ and $\mathrm{S} 18 \mathrm{~K} 5$ are considered to represent a novel species of the genus Glaciecola, for which the name Glaciecola chathamensis sp. nov. is proposed. The type strain is $\mathrm{S} 18 \mathrm{~K} 6^{\top}\left(=\mathrm{JCM} 13645^{\top}=\mathrm{NCIMB} 14146^{\top}\right)$.
\end{abstract}

There have been many reports of micro-organisms that produce exopolysaccharides (EPSs). Some bacterial polysaccharides are produced on an industrial scale and are used as raw materials in food processing and in medical and industrial preparations. It remains possible that new polysaccharide-producing bacteria will be found in various habitats. In attempts to find new polysaccharide-producing bacteria from ocean bottom sediment we have successfully isolated numerous bacteria that produced polysaccharide in our laboratory. We describe here two polysaccharideproducing bacterial strains that were considered to belong to the genus Glaciecola. The genus Glaciecola is a member of the Gammaproteobacteria (Bowman et al., 1998). The physiological and biochemical features, chemotaxonomic characteristics and phylogeny of the two strains, designated S18K6 ${ }^{\mathrm{T}}$ and S18K5, were examined. DNA-DNA relatedness data showed that the strains should be classified as a novel species of the genus Glaciecola.

Sediment samples were collected during the R/V HakuhoMaru cruise (KH-05-2) in 2005. Strains S18K6 ${ }^{\mathrm{T}}$ and S18K5 were isolated by selective enrichment from a sediment sample taken from the Pacific Ocean floor near Chatham Rise at a water depth of $4627 \mathrm{~m}\left(39^{\circ} 59^{\prime} 57^{\prime \prime} \mathrm{S} 169^{\circ} 59^{\prime} 85^{\prime \prime}\right.$

Abbreviation: EPS, exopolysaccharide.

The GenBank/EMBL/DDBJ accession numbers for the 16S rRNA gene sequences of $\mathrm{S} 18 \mathrm{~K} 6^{\top}$ and $\mathrm{S} 18 \mathrm{~K} 5$ are $\mathrm{AB} 247623$ and AB247624, respectively.
$\mathrm{W})$. The sediment sample was inoculated in $10 \mathrm{ml}$ mineral salts medium containing (per litre) $5 \mathrm{~g}$ peptone, $10 \mathrm{~g}$ glucose, 0.008 g Na $\mathrm{HPO}_{4}, 0.0016 \mathrm{~g} \mathrm{NH}_{4} \mathrm{NO}_{3}, 23.4 \mathrm{~g}$ $\mathrm{NaCl}, 0.7 \mathrm{~g} \mathrm{KCl}, 10.6 \mathrm{~g} \mathrm{MgCl}_{2} \cdot 6 \mathrm{H}_{2} \mathrm{O}, 1 \cdot 1 \mathrm{~g} \mathrm{CaCl}_{2}, 3.9 \mathrm{~g}$ $\mathrm{Na}_{2} \mathrm{SO}_{4}, 0 \cdot 2 \mathrm{~g} \mathrm{NaHCO}_{3}, 1 \cdot 0 \mathrm{~g}\left(\mathrm{NH}_{4}\right)_{2} \mathrm{SO}_{4}, 0 \cdot 01 \mathrm{~g} \mathrm{~K}_{2} \mathrm{HPO}_{4}$ and $6.05 \mathrm{~g}$ Tris, $\mathrm{pH} 7 \cdot 8$. This medium was incubated at $15^{\circ} \mathrm{C}$ with shaking at 150 r.p.m. After being incubated for several days, a portion of the suspension was transferred into $10 \mathrm{ml}$ fresh medium and the medium was then reincubated. After three successive transfers, the suspension was plated onto solid medium to isolate pure cultures. The isolates were checked for their ability to produce EPSs by adding ethanol to the broth supernatant. Of the strains isolated, $\mathrm{S} 18 \mathrm{~K}^{\mathrm{T}}$ and $\mathrm{S} 18 \mathrm{~K} 5$, which showed good EPS production, were selected for further study. To investigate their morphological and physiological characteristics, strains $\mathrm{S} 18 \mathrm{~K}^{\mathrm{T}}{ }^{\mathrm{a}}$ and $\mathrm{S} 18 \mathrm{~K} 5$ were cultivated aerobically at $15^{\circ} \mathrm{C}$ on marine agar 2216 (Difco). Cell morphology was examined via transmission electron microscopy. Cells were fixed with $1 \%(\mathrm{v} / \mathrm{v})$ glutaraldehyde and negatively stained with $4 \%(\mathrm{w} / \mathrm{v})$ aqueous uranyl acetate and carbon film. Samples were examined under a JEOL JEM-1210 transmission electron microscope.

Strains $\mathrm{S} 18 \mathrm{~K}^{\mathrm{T}}$ and $\mathrm{S} 18 \mathrm{~K} 5$ were also examined for a range of phenotypic properties using standard procedures (Komagata, 1985). Growth at different temperatures $\left(4-40^{\circ} \mathrm{C}\right)$ and $\mathrm{pH}$ values $(5 \cdot 0-10 \cdot 0)$ was tested using marine broth 2216. Additional biochemical tests with the 
API 20NE test kit (bioMérieux) and the Biolog GN MicroPlate method were performed as described by the manufacturers, except that strains were suspended in $3 \%$ $\mathrm{NaCl}$.

Whole-cell fatty acids were extracted from $100 \mathrm{mg}$ freezedried cells, which were cultivated on marine broth 2216 , and esterified by acid methanolysis. The methyl esters were analysed using a gas-liquid chromatograph equipped with a flame-ionization detector (model GC 353; GL Sciences) and an SP-2560 column $(0.25 \mathrm{~mm} \times 100 \mathrm{~m}, 0.2 \mu \mathrm{m}$ film; Supelco) at an oven temperature of $140{ }^{\circ} \mathrm{C}$ for $15 \mathrm{~min}$. These methyl esters were then identified by comparing their retention times with those of fatty acid methyl ester standards purchased from Supelco and GL Sciences, and by using a GC/MS system (model INCOS 50; Finnigan MAT) connected to a gas-liquid chromatograph (model 3400; Varian).

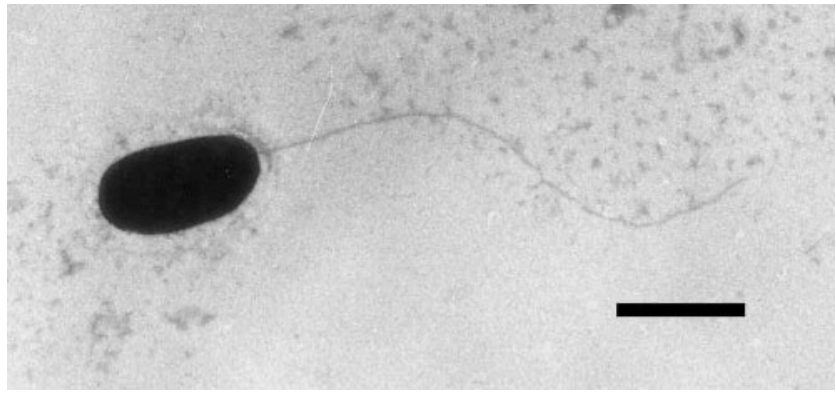

Fig. 1. Transmission electron micrograph of a negatively stained cell of strain $\mathrm{S} 18 \mathrm{~K} 6^{\top}$. Bar, $1 \mu \mathrm{m}$.

DNA was prepared from bacterial cells according to the method of Marmur (1961). The G $+\mathrm{C}$ content of the DNA was determined according to the method of Tamaoka \&

Table 1. Phenotypic characteristics of strains $\mathrm{S} 18 \mathrm{~K} 6^{\top}$ and $\mathrm{S} 18 \mathrm{~K} 5$ and of recognized Glaciecola species

Taxa: 1, strain S18K6 ${ }^{\mathrm{T}}$; 2, strain S18K5; 3, Glaciecola mesophila; 4, Glaciecola polaris; 5, Glaciecola punicea; 6, Glaciecola pallidula. Data are taken from Bowman et al. (1998), Romanenko et al. (2003), Van Trappen et al. (2004) and this study. Symbols: +, positive; -, negative; $\mathrm{V}+$, variable between strains, type strain positive; $\mathrm{V}-$, variable between strains, type strain negative; $\mathrm{W}$, weak or delayed; ND, not determined. All were positive for the following tests: motility, sodium ion requirement for growth, oxidase, catalase, growth at $7-20^{\circ} \mathrm{C}$ and growth in $1-6 \%(\mathrm{w} / \mathrm{v}) \mathrm{NaCl}$. All were negative for growth at $37^{\circ} \mathrm{C}$, the indole reaction, arginine dihydrolase, and for utilization of citrate, L-arabinose, L-histidine, L-threonine and $\mathrm{N}$-acetylglucosamine.

\begin{tabular}{|c|c|c|c|c|c|c|}
\hline Characteristic & 1 & 2 & 3 & 4 & 5 & 6 \\
\hline Pigmentation & None & None & None & None & Pink-red & Pale pink \\
\hline Growth at $25^{\circ} \mathrm{C}$ & + & + & + & + & + & - \\
\hline Growth in $10 \%(\mathrm{w} / \mathrm{v}) \mathrm{NaCl}$ & + & + & $\mathrm{v}-$ & + & - & - \\
\hline Nitrate reduction & - & - & + & - & - & - \\
\hline \multicolumn{7}{|l|}{ Hydrolysis of: } \\
\hline Urea & - & - & - & - & $\mathrm{w}$ & - \\
\hline Gelatin & - & + & - & - & - & - \\
\hline Aesculin & + & + & $\mathrm{w}$ & + & $\mathrm{v}+$ & - \\
\hline$\beta$-Galactosidase & + & + & + & + & + & - \\
\hline Production of EPS & + & + & + & $\mathrm{w}$ & ND & $\mathrm{ND}$ \\
\hline \multicolumn{7}{|l|}{ Utilization of: } \\
\hline Glycogen & - & + & + & + & - & + \\
\hline Dextrin & + & + & + & + & - & + \\
\hline D-Mannitol & + & + & + & + & - & - \\
\hline Glycerol & - & - & - & - & - & + \\
\hline Sucrose & + & + & $v+$ & + & - & - \\
\hline D-Mannose & + & + & $v+$ & + & - & - \\
\hline L-Rhamnose & + & + & - & - & - & - \\
\hline D-Fructose, D-trehalose & + & + & $\mathrm{v}+$ & + & - & - \\
\hline L-Leucine & + & + & - & + & - & - \\
\hline L-Proline & + & + & - & $\mathrm{w}$ & + & - \\
\hline Acetate & - & - & - & + & - & + \\
\hline L-Glutamate & + & + & $v+$ & + & - & + \\
\hline DL-Lactate & - & - & - & - & - & + \\
\hline Succinate & $\mathrm{w}$ & $\mathrm{w}$ & - & - & + & - \\
\hline Propionate & $\mathrm{w}$ & $\mathrm{w}$ & - & + & - & - \\
\hline DNA G $+\mathrm{C}$ content $(\mathrm{mol} \%)$ & 44·8 (HPLC) & $46 \cdot 3$ (HPLC) & $44 \cdot 6-44 \cdot 8\left(T_{\mathrm{m}}\right)$ & 44·2 (HPLC) & $44-46\left(T_{\mathrm{m}}\right)$ & $40\left(T_{\mathrm{m}}\right)$ \\
\hline
\end{tabular}


Komagata (1984). Levels of DNA-DNA relatedness were determined fluorometrically according to the method of Ezaki et al. (1989) using photobiotin-labelled DNA probes and microplates.

The $16 \mathrm{~S}$ rRNA gene was amplified by using the PCR method with primers $9 \mathrm{~F}\left(5^{\prime}\right.$-GAGTTTGATCCTGGCTCAG- $\left.3^{\prime}\right)$ and 1541R (5'-AAGGAGGTGATCCAGCC-3'). The PCR product, approximately $1.5 \mathrm{~kb}$ in size, was sequenced by the dideoxynucleotide chain-termination method, using a BigDye terminator cycle sequencing ready kit (version 3.0; Applied Biosystems) and a DNA sequencer (ABI Prism 3100). Primers 9F, 339F, 686F, 1099F and 357R were used in the gene-sequencing reaction. Multiple alignments of the sequences were performed and the nucleotide-substitution rate $\left(K_{\text {nuc }}\right.$ value) was calculated. A phylogenetic tree was constructed according to the neighbour-joining method (Kimura, 1980; Saitou \& Nei, 1987) by using the CLUSTAL W program (Thompson et al., 1994). Sequence similarity was calculated by using the GENETYX computer program (Software Development).

Cultural properties, cell morphology (Fig. 1), motility and the results of some physiological tests of strain $S 18 \mathrm{~K}^{\mathrm{T}}$ are given in the species description. Cells were motile with a single polar flagellum. The strains required sodium ions for growth and grew in $1-10 \% \mathrm{NaCl}$; they grew at $4-30{ }^{\circ} \mathrm{C}$ but not at or above $37^{\circ} \mathrm{C}$. The phenotypic properties of strains $\mathrm{S} 18 \mathrm{~K} 6^{\mathrm{T}}$ and S18K5 and reference members of the genus Glaciecola are compared in Table 1.

Strains S18K6 ${ }^{\mathrm{T}}$ and S18K5 possessed similar whole-cell fatty acid profiles and predominant fatty acids. The fatty acid profile of strain $\mathrm{S} 18 \mathrm{~K}^{\mathrm{T}}$ is as follows: $27 \cdot 2 \% \mathrm{C}_{16: 0}, 22 \cdot 7 \%$ $\mathrm{C}_{16: 1} \omega 7 c, \quad 14 \cdot 6 \% \quad \mathrm{C}_{18: 1} \omega 7 c, \quad 9 \cdot 5 \% \quad \mathrm{C}_{16: 1} \omega 5 c, \quad 8 \cdot 3 \%$ $\mathrm{C}_{17: 1} \omega 8 c, 4 \cdot 6 \% \mathrm{C}_{12: 0}, 4 \cdot 1 \% \mathrm{C}_{17: 0}, 2 \cdot 8 \% \mathrm{C}_{15: 0}, 2 \cdot 0 \%$ $\mathrm{C}_{14: 0}, 1 \cdot 6 \% \mathrm{C}_{17: 1} \omega 6 c, 1 \cdot 6 \% \mathrm{C}_{18: 1} \omega 5 c$ and $1.2 \% \mathrm{C}_{18: 0}$. The profile of strain S18K5 is as follows: $24 \cdot 3 \% \mathrm{C}_{16: 0}, 21 \cdot 1 \%$ $\mathrm{C}_{16: 1} \omega 7 c, \quad 14.0 \% \quad \mathrm{C}_{18: 1} \omega 7 c, \quad 8.9 \% \quad \mathrm{C}_{16: 1} \omega 5 c, \quad 9.5 \%$ $\mathrm{C}_{17: 1} \omega 8 c, 7 \cdot 3 \% \mathrm{C}_{12: 0}, 4 \cdot 6 \% \mathrm{C}_{17: 0}, 2 \cdot 4 \% \mathrm{C}_{15: 0}, 2 \cdot 4 \%$ $\mathrm{C}_{14: 0}, 2 \cdot 0 \% \mathrm{C}_{17: 1} \omega 6 c, 1 \cdot 5 \% \mathrm{C}_{18: 1} \omega 5 c$ and $1 \cdot 9 \% \mathrm{C}_{18: 0}$. The fatty acid profiles of strains $\mathrm{S} 18 \mathrm{~K}^{\mathrm{T}}$ and $\mathrm{S} 18 \mathrm{~K} 5$ clearly resemble those determined for other marine genera of the Gammaproteobacteria, e.g. Alteromonas, Pseudoalteromonas and Glaciecola (Ivanova et al., 2000).

The almost-complete 16S rRNA gene sequence of strain $\mathrm{S} 18 \mathrm{~K}^{\mathrm{T}}{ }^{\mathrm{T}}$ (1496 nt) was compared with all other sequences in the database, and a phylogenetic tree was constructed using related taxa. The phylogenetic tree indicated that strains $\mathrm{S} 18 \mathrm{~K}^{\mathrm{T}}$ and S18K5 fall within the evolutionary radius of the genus Glaciecola (Fig. 2). 16S rRNA gene sequence

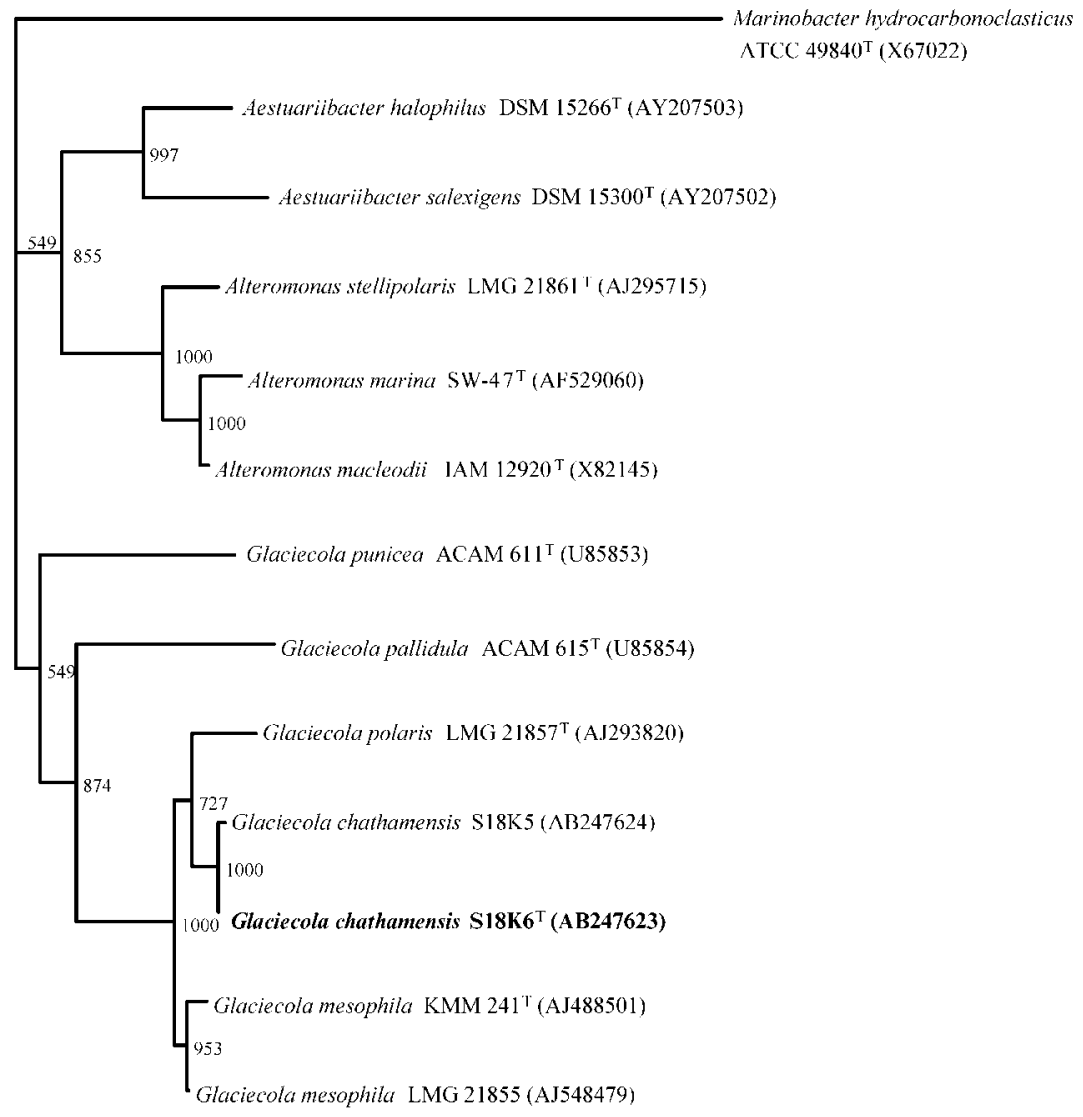

0.1
Fig. 2. Phylogenetic tree derived from $16 \mathrm{~S}$ rRNA gene sequence data of strains S18K6 ${ }^{\top}$ and S18K5, recognized species of the genus Glaciecola and other related organisms based on the neighbour-joining method. Numbers indicate bootstrap values of greater than 500 . Bar, $0.1 K_{\text {nuc }}$ units. 
similarities of strain $\mathrm{S} 18 \mathrm{~K}^{\mathrm{T}}$ to S18K5, Glaciecola mesophila LMG 21855, G. mesophila KMM $241^{\mathrm{T}}$ and Glaciecola polaris LMG $21857^{\mathrm{T}}$ were $99 \cdot 9,99 \cdot 1,98 \cdot 7$ and $98 \cdot 5 \%$, respectively. Accordingly, strains $\mathrm{S} 18 \mathrm{~K}^{\mathrm{T}}{ }^{\mathrm{T}}$ and S18K5 are considered to belong within the genus Glaciecola.

Genomic relatedness between strains $\mathrm{S} 18 \mathrm{~K} 6^{\mathrm{T}}$ and $\mathrm{S} 18 \mathrm{~K} 5$ and their closest phylogenetic relatives, G. mesophila LMG 21855, G. mesophila KMM $241^{\mathrm{T}}$ and G. polaris LMG $21857^{\mathrm{T}}$, was determined by DNA-DNA hybridization experiments. On this basis, strain $\mathrm{S}_{18 \mathrm{~K} 6^{\mathrm{T}}}$ is closely related to S18K5, having a DNA-DNA reassociation value near $70 \%$, which is generally accepted as the threshold for species delineation (Wayne et al., 1987). Levels of hybridization between strain S18K6 ${ }^{\mathrm{T}}$ and G. mesophila LMG 21855, G. mesophila KMM $241^{\mathrm{T}}$ and G. polaris LMG $21857^{\mathrm{T}}$ were 22,23 and $10 \%$, respectively. On the basis of the above results, strains S18K6 ${ }^{\mathrm{T}}$ and S18K5 were considered to represent a novel species.

The DNA G $+\mathrm{C}$ contents of $\mathrm{S} 18 \mathrm{~K}^{\mathrm{T}}{ }^{\mathrm{T}}$ and $\mathrm{S} 18 \mathrm{~K} 5$, which were determined using an HPLC method, were $44 \cdot 8$ and $46 \cdot 3 \%$, respectively. These values are consistent with those of recognized members of the genus Glaciecola, which range between 40 and 46 mol\% (Bowman et al., 1998).

On the basis of this polyphasic taxonomic analysis, strains S18K6 ${ }^{\mathrm{T}}$ and S18K5 are considered to represent a novel species of the genus Glaciecola, for which the name Glaciecola chathamensis sp. nov. is proposed.

\section{Description of Glaciecola chathamensis sp. nov.}

Glaciecola chathamensis (chat.ham.en'sis. N.L. fem. adj. chathamensis pertaining to Chatham Rise, from where the type strain was isolated).

Aerobic, Gram-negative, oxidase- and catalase-positive, non-pigmented, non-spore-forming, ovoid or curved rodshaped cells, $1 \cdot 2-2 \cdot 0 \mu \mathrm{m}$ long and $0 \cdot 6-1 \cdot 0 \mu \mathrm{m}$ in diameter, motile by means of a single polar flagellum. On marine agar, forms smooth, convex, non-pigmented colonies. The temperature range for growth is $4-30{ }^{\circ} \mathrm{C}$; no growth occurs at or above $37^{\circ} \mathrm{C}$. Growth is observed on marine agar with up to $10 \%(\mathrm{w} / \mathrm{v}) \mathrm{NaCl}$, indicating that cells are moderately halophilic and psychrotolerant. The $\mathrm{pH}$ range for growth is $5 \cdot 0-9 \cdot 0$. Produces EPS. Positive for hydrolysis of aesculin, and for activity of $\beta$-galactosidase. Able to utilize $\alpha$-cyclodextrin, dextrin, Tweens 40 and 80 , D-fructose, Dgalactose, $\alpha$-D-glucose, myo-inositol, $\alpha$-D-lactose, maltose, D-mannitol, D-mannose, D-raffinose, L-rhamnose, sucrose, D-trehalose, turanose, L-alanine, methyl pyruvate, L-glutamic acid, L-leucine and L-proline. Negative for indole production, hydrolysis of urea and nitrate reduction.
Negative for arginine dihydrolase activity. Cannot utilize citrate, L-arabinose, L-histidine, L-threonine, $\mathrm{N}$-acetylglucosamine, adonitol, cellobiose, erythritol, L-fucose, Dsorbitol, xylitol, acetic acid, formic acid, D-gluconic acid, itaconic acid, DL-lactic acid, malonic acid, D-alanine, inosine or glycerol. Predominant fatty acids are $\mathrm{C}_{16: 0}, \mathrm{C}_{16: 1} \omega 7 c$ and $\mathrm{C}_{18: 1} \omega 7 c$.

The DNA G $+\mathrm{C}$ content of the type strain is $44 \cdot 8 \%$ (HPLC method). The type strain, $\mathrm{S} 18 \mathrm{~K} 6^{\mathrm{T}}\left(=\mathrm{JCM} 13645^{\mathrm{T}}=\mathrm{NCIMB}\right.$ $14146^{\mathrm{T}}$ ), was isolated from sediment of the Pacific Ocean floor near Chatham Rise.

\section{References}

Bowman, J. P., McCammon, S. A., Brown, J. L. \& McMeekin, T. A. (1998). Glaciecola punicea gen. nov., sp. nov. and Glaciecola pallidula gen. nov., sp. nov., psychrophilic bacteria from Antarctic sea-ice habitats. Int J Syst Bacteriol 48, 1213-1222.

Ezaki, T., Hashimoto, Y. \& Yabuuchi, E. (1989). Fluorometric deoxyribonucleic acid-deoxyribonucleic acid hybridization in which radioisotopes are used to determine genetic relatedness among bacterial strains. Int J Syst Bacteriol 39, 224-229.

Ivanova, E. P., Zhukova, N. V., Svetashev, V. I., Gorshkova, N. M., Kurilenko, V. V., Frolova, G. M. \& Mikhailov, V. V. (2000). Evaluation of phospholipids and fatty acid composition as chemotaxonomic markers of Alteromonas-like proteobacteria. Curr Microbiol 41, 341-345.

Kimura, M. (1980). A simple method for estimating evolutionary rates of base substitutions through comparative studies of nucleotide sequences. J Mol Evol 16, 111-120.

Komagata, K. (1985). Bacteria(1) - the aerobic bacteria. In Classification and Identification of Microorganisms, vol. 2, pp. 99-161. Edited by T. Hasegawa. Tokyo: Gakkai Shuppan.

Marmur, J. (1961). A procedure for the isolation of deoxyribonucleic acid from microorganisms. J Mol Biol 3, 208-218.

Romanenko, L. A., Zhukova, N. V., Rohde, M., Lysenko, A. M., Mikhailov, V. V. \& Stackebrandt, E. (2003). Glaciecola mesophila sp. nov., a novel marine agar-digesting bacterium. Int $J$ Syst Evol Microbiol 53, 647-651.

Saitou, N. \& Nei, M. (1987). The neighbor-joining method: a new method for reconstructing phylogenetic trees. Mol Biol Evol 4, 406-425.

Tamaoka, J. \& Komagata, K. (1984). Determination of DNA base composition by reversed-phase high-performance liquid chromatography. FEMS Microbiol Lett 25, 125-128.

Thompson, J. D., Higgins, D. G. \& Gibson, T. J. (1994). CLUSTAL W: improving the sensitivity of progressive multiple sequence alignment through sequence weighting, position-specific gap penalties and weight matrix choice. Nucleic Acids Res 22, 4673-4680.

Van Trappen, S., Tan, T.-L., Yang, J., Mergaert, J. \& Swings, J. (2004). Glaciecola polaris sp. nov., a novel budding and prosthecate bacterium from the Arctic Ocean, and emended description of the genus Glaciecola. Int J Syst Evol Microbiol 54, 1765-1771.

Wayne, L. G., Brenner, D. J., Colwell, R. R. \& 9 other authors (1987). Report of the ad hoc committee on reconciliation of approaches to bacterial systematics. Int J Syst Bacteriol 37, 463-464. 